\title{
Hemoglobin Measurement
}

National Cancer Institute

\section{Source}

National Cancer Institute. Hemoglobin Measurement. NCI Thesaurus. Code C64848.

A quantitative measurement of the amount of hemoglobin present in a sample. 